РОЗВИТОК РЕФЛЕКСИВНОЇ КУЛЬТУРИ У МАЙБУТНІХ ОФІЦЕРІВ ЗБРОЙНИХ СИЛ УКРАЇНИ У ПРОЦЕСІ ПРОФЕСІЙНОЇ ПІДГОТОВКИ

\title{
DEVELOPMENT OF REFLECTIVE CULTURE FOR FUTURE OFFICERS OF THE ARMED FORCES OF UKRAINE IN THE PROFESSIONAL PREPARATION PROCESS
}

\begin{abstract}
Стаття присвячена аналізу актуальної психолого-педагогічної проблеми пошуку шляхів формування та розвитку рефрлексивної культури у майбутніх офріцерів Збройних Сил України у процесі професійної підготовки у вищих військових навчальних закладах. Визначено, що рефллексивна культура майбутнього офріцера, передбачаючи усвідомлення самого себе та системне переосмислення змісту результатів власної діяльності, є особистісною й одночасно професійною якістю курсанта як військовослужбовця, майбутнього управлінця та спеціаліста окремого напряму просресійної діяльності, створює підгрунтя для його постійного розвитку та самовдосконалення як особистості та військового профресіонала. Встановлено, що ресрлексивне ставлення курсанта як суб'єкта до освітньої та військово-просьесійної діяльності та до аналогічної діяльності інших суб'єктів освітньо-виховного процесу вищого військового навчального закладу $\epsilon$ визначальною психолого-педагогічною умовою усвідомлення себе як військового профресіонала й управлінця, критичного аналізу власної діяльності та діяльності інших суб'єктів, вироблення власного бачення шляхів самовдосконалення. З'ясовано, що зміни в підходах до забезпечення фрункціонування системи військово-професійної підготовки у вищих військових навчальних закладах, їі побудова на визнанні ресрлексії просресійно важливою якістю майбутніх офріцерів, здійснення комплексу заходів щодо розвитку вмінь рефрлексії профресійної діяльності забезпечить фоормування офріцера, здатного до свідомого ухвалення виваженого й обгрунтованого управлінського рішення, його аналізу й об'єктного прогнозу наслідків, $є$ винятково важливим 3 огляду на рівень відповідальності офріцера за виконання службово-бойових завдань, життя та здоров'я підпорядкованого особового складу. Узагальнено погляди науковців на категорії «рефрлексія» та «рефрлексивна культура майбутнього офріцера» в педагогічному та психологічному аспектах. Ключові слова: курсант, майбутній офріцер, ресрлексія, рефрлексивна культура, освітньо-
\end{abstract}

виховний прочес, вищий військовий навчальний заклад.

The article is devoted to the analysis of the actual psychological and pedagogical problem of finding ways of formation and development of reflexive culture among future officers of the Armed Forces of Ukraine in the process of professional training in higher military educational institutions. It is determined that the reflexive culture of a future officer, in particular, by foreseeing the awareness of himself and the systematic rethinking of the content of the results of his own activities, is a personal and, at the same time, professional quality of the cadet as a serviceman, future manager and specialist of a separate line of professional activity, creates the basis for his constant development and self-improvement as a person and as a military professional. It was established that the reflexive attitude of the cadet as a subject to educational and military professional activities and to the similar activities of other subjects of the educational process of the higher military educational institution is the determining psychological and pedagogical condition for the perception of himself as a military professional and manager, a critical analysis of his own activities and activities of other actors, development of own vision of ways of self-improvement. It was clarified that changes in the approaches to ensuring the functioning of the system of military-vocational training in the Internal Affairs Center, its construction on recognizing the reflection of the professional-important quality of future officers, the implementation of a set of measures to develop the skills of reflection of professional activities will ensure the formation of an officer capable of deliberately adopting a weighted and reasonable management decision, its analysis and objective prediction of the consequences, is extremely important given the level of responsibility of the officer for the performance of military-fighting Health, life and health of subordinate personnel. A generalization of the views of scholars in the category "reflection" and "reflexive culture of the future officer" from the psychological and pedagogical point of view is made.

Key words: cadet, future officer, reflection, reflexive culture, educational and educational process, higher military educational institution.
Постановка проблеми у загальному вигляді. Профресійна діяльність офріцера є специфрічною, насамперед через інтеграцію в ній управлінських, правових, соціальних, психологічних, етичних та інших аспектів, пов'язаних із необхідністю ухвалення офріцерами самостійних і обґрунтованих рішень.

У зв'язку з цим важливим завданням є фрормування в офріцерів адекватного розуміння необхідності суб'єктного вкладу в зміну якісних параметрів об'єкта діяльності, розвиток рефлексивної культури у майбутніх офріцерів Збройних Сил Укра- їни (далі - 3СУ) у процесі профресійної підготовки як основи їх суб'єктної компетентності.

Аналіз останніх досліджень і публікацій. У контексті дослідження питання організації та розвитку психіки людини рефлексія як наукова категорія перебувала у спектрі уваги І. Сечєнова, Б. Ананьєва, П. Блонського, Л. Виготського, С. Рубінштейна та ін., котрі вказану десрініцію визначали як важливий чинник становлення і розвитку особистості.

Не втрачає актуальності дослідження питання реорлексії в сучасному науковому дискурсі, 
зокрема вона була предметом наукового пошуку А. Анікіної, А. Асмолова, М. Бахтіна, І. Беха, Г. Бізяевої, Л. Деркача, А. Зака, Е. Зеера, Є. Ісаєва, Я. Коломінського, А. Карпова, С. Кондратьєва, В. Кривошеєва, В. Лефевра, Б. Ломова, М. Найдьонова, М. Савчина, В. Сластьоніна, В. Слободчикова, І. Семенова, С. Степанова, Г. щедровицького, В. Якуніна та ін.

Актуальним $€$ питання дослідження ресрлексії серед зарубіжних науковців. Так, рефлексію та її вплив на розвиток активного досвіду і практики вивчають С. Вайлдман і Д. Колб, усвідомлення стратегій навчання через рефлексивне сприйняття перебуває у центрі уваги ряду дослідників, серед яких С. Аткінс, К. Марфрі, Р. Вайт, Д. Кірпатрик та ін., рефлексивні моделі освіти досліджують М. Ліпман і Р. Познер, питання розвитку рефрлексії у груповій взаємодії - Р. Кулд, Дж. Селлер та ін.

Виділення невирішених раніше частин загальної проблеми. Сучасні умови виконання службово-бойових завдань офріцерським складом вимагають нових підходів до організації їхньої професійної підготовки у вищих військових навчальних закладах (далі - ВВН3), пошуку шляхів індивідуалізації освітнього процесу та забезпечення умов самореалізації курсанта як військового профресіонала й особистості на різних етапах службової діяльності.

Актуальною є проблема пошуку шляхів фрормування майбутнього офріцера зі сорормованим креативним мисленням, здатного об'єктивно оцінювати ситуацію, самостійно ухвалювати виважене рішення та відповідати за нього, аналізувати власну службову діяльність через потенціал профресійної рефрлексії, що створює передумови швидкої та безболісної їх адаптації до умов виконання завдань і їх реалізації.

Мета статті - теоретичний аналіз умов та особливостей розвитку рефлексивної культури у майбутніх офріцерів ЗСУ у процесі профресійної підготовки у ВВНЗ.

Виклад основного матеріалу. Перші згадки про ресрлексію знаходимо у працях давньогрецьких фрілософів Сократа, Платона й Аристотеля, подальшого розвитку ця дефініція набула у напрацюваннях представників західноєвропейської фрілософрії XVII-XVIII ст. На думку Ф. Бекона, знання можна отримати тільки завдяки спостереженню, аналізу, порівнянню й експерименту, автор аналітичного методу пізнання Р. Декарт вказував, що в його основі $€$ виділення складників об'єкта пізнання та їх вивчення окремо від інших. На противагу Р. Декарту Дж. Локк стверджував, що джерелом отримання знань є досвід і почуття. Досвід фрілософ поділяв на внутрішній і зовнішній: якщо отримання зовнішнього досвіду відбувається через органи чуття, то внутрішній досвід, на думку Дж. Локка, є рефлексією [6].
Рефлексію як пізнання трактував І. Кант, тоді як Г. Гегель вважав її рушійною силою розвитку людини, передбачаючи рефрлексію суб'єктивну, спрямовану на людину, та рефлексію об'єктивну, що проявляється у діяльності. На думку А. Шопенгауера, підґрунтям рефрлексії є інтуїція як шлях до пізнання. Як зазначав німецький фрілософр В. Дільтей, «розуміння власного внутрішнього світу досягається шляхом інтроспекції, тобто самоспостереження, реорлексії. Розуміння ж «чужого світу» здійснюється шляхом «вживання», «співпереживання» [6, с. 176, 177].

Розгляд рефрлексії у фрілософрії переважно здійснюється через розуміння суб'єктом причин і передумов фрормування поглядів і власних суджень, що $€$ одним із методів розвитку мислення, пізнання себе та інших людей через усвідомлення як власних поглядів і думок про інших, так і усвідомлення поглядів та думок інших людей про себе, забезпечуючи перехід від включення самосвідомості в діяльність до фрормування ставлення суб'єкта до діяльності як об'єктивної дійсності й усвідомлення себе в ній.

Подальшого розвитку наукова десрініція «рефрлексія» здобула переважно у психології та педагогіці. Ця десрініція досліджувалася психологами через потенційну можливість особистості здійснити аналіз власного мислення, спрямувати погляд всередину самої себе.

На думку С. Рубінштейна, рефлексія $€$ основою існування людини та передумовою способів її існування: «Перший - життя, що не виходить за межі безпосередніх зв'язків, у яких живе людина: спочатку батько і мати, потім подруги, вчителі, потім чоловік, діти і т. д. Тут людина вся всередині життя, всяке її ставлення - це ставлення до окремих явищ, але не до життя загалом. Другий спосіб існування пов'язаний із появою рефлексії. Вона наче призупиняє, перериває цей безперервний процес життя і виводить людину подумки за його межі. Людина наче посідає позицію поза ним» [3, с. 90].

Г. Костюк підкреслював, що «важливу роль в успішному перебігу розуміння відіграє вміння аналізувати свій власний процес мислення» [2].

Здійснення аналізу власного процесу мислення, на наше переконання, забезпечує усвідомлення суб'єктом особливостей і передумов сприйняття й оцінки його іншими шляхом аналізу себе як об'єкта дослідження та спостереження через звернення уваги на власне буття, знання, вчинки, думки та почуття. Усвідомлюючи їх, суб'єкт аналогічним чином аналізує ставлення інших людей до себе, що з огляду на особливості військово-професійної діяльності зумовлює виняткову важливість рефлексії у процесі профресіоналізації майбутніх офріцерів.

Ми поділяємо погляди В. Слободчикова та Г. Цукермана, котрі рефлексію визначають як уні- 
версальний психічний механізм подолання меж свого способу життя [5, с. 27].

У процесі пізнання суб'єкт здійснює самоаналіз своїх станів і здійснених вчинків через призму власного досвіду й освіченості, рівня розвитку особистої моралі, визначаючи власні норми та межі їх контролю в подальшій діяльності. Спрямування мислення людини на свій внутрішній світ, на думку І. Беха, відмежовує особистісне розуміння рефлексії від інтелектуального. Виокремлюючи форми особистісної рефрлексії - регулятивну, визначальну, синтезуючу, створювальну, - науковець зазначає, що особистісна ресрлексія пов'язана 3 духовним Я особистості та забезпечує її саморозвиток [1].

Узагальнюючи погляди науковців на дефініцію «рефрлексія», ми погоджуємося 3 І. Семеновим і С. Степановим, які аргументовано визначають ії як «переосмислення людиною відносин із предметно-соціальним світом (що актуалізуються внаслідок спілкування з іншими людьми й активного засвоєння норм і засобів різних діяльностей), яке виражається, з одного боку, у побудові нових образів себе, що реалізуються у вигляді відповідних вчинків, а 3 іншого - у виробленні більш адекватних знань про світ із їх подальшим утіленням у вигляді конкретних дій. Рефлексія не лише забезпечує дисреренціацію в людському «Я» окремих підструктур, наприклад, «Я - фрізичне тіло», «Я - суспільна істота», «Я-творець», але і їх інтеграцію в неповторному цілісному «Я» [4, с. 37-38], що повною мірою притаманне потребам військовопрофесійної діяльності сучасного офріцера.

В основі ресрлексії як новоутворення психіки у процесі розвитку особистості курсанта як суб'єкта освітньої та військово-професійної діяльності, на наше переконання, лежить сприйняття себе та власної діяльності, сприйняття іншими його та його діяльності, що стимулює аналіз сприйняття i, як наслідок, фрормування та становлення зрілої та відповідальної особистості майбутнього офіцера.

Виходячи 3 актуальності рефрлексії у профресіоналізації курсанта під час навчання у ВВН3, рефлексивну культуру майбутнього офріцера вважаємо системним новоутворенням особистості курсанта внаслідок його внутрішньої активності як суб'єкта військово-профресійної та освітньої діяльності у процесі профресійної підготовки у ВВН3, що забезпечує фрормування ставлення до діяльності та до себе в цій діяльності.

Рефлексивна культура майбутнього офіцера як складова частина культури військового профресіонала реалізується через рефлексивні механізми у професіоналізації офріцерів, які ми визначаємо як процес вирішення різнопланових завдань, спрямованих на взаємне збагачення особистості майбутнього офріцера, фрормування його світогляду та відповідальності за власне буття. Функціонування рефрлексивних механізмів зумовлюється впливом ряду фракторів, серед яких визначальними щодо профресіоналізації майбутнього осріцера $€$ рівень розвитку його самосвідомості, мотивація та сорормованість мотивів діяльності, здатність до аналізу власних дій та ідентифікації себе з іншими.

В основі фоорування рефрлексивної культури майбутніх офріцерів ЗСУ як основи їх суб'єктної компетентності лежать принципи теорії про закономірності розвитку людини та спеціаліста. До ключових ми відносимо такі принципи:

- суб'єктності, що передбачає орормування особистості майбутнього офріцера під час навчання у ВВНЗ як суб'єкта особистісно-професійного саморозвитку та самовдосконалення, 3 належним рівнем сорормованості здатності й усвідомленої потреби самостійного мислення, активності в освітній і військово-профресійній діяльності;

- інтегративності, що передбачає об'єднання знань і досвіду закономірностей фрормування та розвитку рефрлексивної компетентності спеціаліста та майбутнього офріцера зокрема;

- системності, що передбачає узагальнення та вироблення структури образу особистості майбутнього офріцера 3 належним рівнем сорормованості рефлективної компетентності.

Серед фрункцій, які є визначальними з огляду на потребу фрормування рефлексивної культури майбутнього офріцера, ми виокремлюємо: розвиваючу, соціальну, пізнавальну, регулятивну та інтегруючу функції.

Оскільки сорормована рефрлексивна культура майбутнього офріцера стимулює самоаналіз, оцінку курсантом свого «Я», виокремлюючи об'єктом самопізнання його власне «Я», для розвитку рефлексії та фрормування рефрлективної культури курсанта під час навчання у ВВНЗ необхідною $є$ реалізація таких умов:

- налагодження, підтримання та розвиток вербального та невербального зворотного зв'язку між суб'єктами освітньо-виховного процесу ВВН3;

- фрормування у курсанта потреби у постійному співвіднесенні результатів своєї діяльності та їх порівнянні як із власними, так і з результатами діяльності інших курсантів;

- формування та підтримання стійкої потреби у майбутнього офріцера в самоспостереженні за своїми думками та почуттями, мотивами діяльності, здійсненими вчинками та подальше їх корегування.

Ефективність формування рефлексивної культури майбутнього офріцера як суб'єкта освітньої та військово-профресійної діяльності у ВВНЗ визначається низкою чинників, серед яких: індивідуалізація освітнього процесу, створення умов для практичного виконання майбутнім офріцером завдань військової служби спільно з носіями професійного досвіду, запровадження в освітній процес 
інтерактивних педагогічних технологій, спрямованих на вирішення проблемних ситуацій і пошук нестандартних і нетипових варіантів вирішення службово-бойових ситуацій, визнання пріоритетності ресрлексивних механізмів у забезпеченні функціонування освітнього середовища ВВН3, що $€$ основою фрормування та розвитку рефлексивного стилю мислення у майбутнього офріцера.

Розвиток рефлексивної культури майбутнього офріцера передбачає: свідомий аналіз освітньої та військово-профресійної діяльності на основі ссрормованих мотивів, критичне ставлення до усталених стандартів, вимог, норм і правил організації як освітньої та військово-професійної діяльності у ВВН3, так і організації виконання службовобойових завдань у частинах і підрозділах ЗСУ, свідому активність в освітній і військово-професійній діяльності, самореалізацію себе як військового професіонала та, як наслідок, самоактуалізацію особистості майбутнього у професії.

Висновки. Таким чином, здійснивши аналіз наукових праць, ми визначили, що реалізація зазначених умов $є$ можливою, якщо освітньовиховне середовище ВВНЗ сприятиме розвитку рефлексивного мислення як у курсантів, так і у науково-педагогічних працівників та адміністративнокомандного складу. Без розвитку рефлексивної культури усіх суб'єктів освітнього процесу створення та забезпечення ефективного фрунцціонування суб'єкт-суб'єктних відносин як основи фрормування професійної суб'єктності майбутнього офріцера не вбачається можливим, тоді як побудова системи військово-професійної підготовки у ВВНЗ через визнання рефлексії професійно важливою якістю майбутніх офріцерів, розвиток рефрлективної культури у курсантів, адміністративно-командного складу і науково-педагогічних працівників ВВНЗ та розвиток здатності майбутніх офріцерів до професійної рефлексії у ході освітньо-виховного процесу $€$ однією з визначальних передумов фрормування їхньої професійної суб'єктності.

Перспективи дослідження полягають у розробці методики формування та розвитку рефрлексивної культури у майбутніх офріцерів під час навчання у ВВНЗ.

\section{БІБЛІОГРАФІЧНИЙ СПИСОК:}

1. Бех І.Д. Психологічні механізми сходження особистості до духовних цінностей. Педагогіка і психологія: Науково-теоретичний та інформаційний журнал Академії педагогічних наук України. 2011. № 2. C. 37-44.

2. Костюк Г.С. Избранные психологические труды. Москва, 1988. 304 с.

3. Рубинштейн С.Л. Человек и мир. СанктПетербург, 2012. 224 с.

4. Семенов И.Н., Степанов С.Ю. Рефлексия в организации творческого мышления и саморазвитии личности. Вопросы психологии. 1983. № 2. С. 35-42.

5. Слободчиков В.И. Генезис рефрлексивного сознания в младшем школьном возрасте. Вопросы психологии. 1990. № 3. С. 25-36.

6. Спиркин А.Г. Философрия : учебник. Москва : Гардарики, 2003. 736 с. 